\title{
Publisher Correction: Optimizing the fragment complementation of APEX 2 for detection of specific protein-protein interactions in live cells
}

\author{
Miaomiao Xue ${ }^{1,2}$, Junjie Hou ${ }^{1}$, Linlin Wang ${ }^{1,2}$, Dongwan Cheng ${ }^{1}$, Jingze Lu ${ }^{1}$, Li Zheng ${ }^{1} \&$ \\ Tao Xu $\mathbb{1}^{1,2}$
}

Correction to: Scientific Reports https://doi.org/10.1038/s41598-017-12365-9, published online 27 September 2017

In the previous versions of this Article and the Author Correction published on 20th April 2018, Junjie Hou, Dongwan Cheng, Jingze Lu and Li Zheng were incorrectly affiliated with 'College of Life Sciences, University of Chinese Academy of Sciences, Beijing, 100049, China'. The correct affiliation is listed below:

National Laboratory of Biomacromolecules, CAS Center for Excellence in Biomacromolecules, Institute of Biophysics, Chinese Academy of Sciences, Beijing, 100101, China.

This error has now been corrected in the PDF and HTML versions of the Article, and in the PDF and HTML versions of the Author Correction.

(i) Open Access This article is licensed under a Creative Commons Attribution 4.0 International License, which permits use, sharing, adaptation, distribution and reproduction in any medium or format, as long as you give appropriate credit to the original author(s) and the source, provide a link to the Creative Commons license, and indicate if changes were made. The images or other third party material in this article are included in the article's Creative Commons license, unless indicated otherwise in a credit line to the material. If material is not included in the article's Creative Commons license and your intended use is not permitted by statutory regulation or exceeds the permitted use, you will need to obtain permission directly from the copyright holder. To view a copy of this license, visit http://creativecommons.org/licenses/by/4.0/.

(C) The Author(s) 2018

\footnotetext{
${ }^{1}$ National Laboratory of Biomacromolecules, CAS Center for Excellence in Biomacromolecules, Institute of Biophysics, Chinese Academy of Sciences, Beijing, 100101, China. ${ }^{2}$ College of Life Sciences, University of Chinese Academy of Sciences, Beijing, 100049, China. Miaomiao Xue and Junjie Hou contributed equally to this work. Correspondence and requests for materials should be addressed to L.Z. (email: zhengli@ibp.ac.cn) or T.X. (email: xutao@ibp.ac.cn)
} 